\title{
PENGENDALIAN PEREDARAN MINUMAN BERALKOHOL DALAM MENCEGAH MENINGKATNYA TINDAK PIDANA KRIMINAL DI WILAYAH HUKUM POLRES BOYOLALI
}

\author{
Yulianus Dica Ariseno Adi \\ Email : dicaariseno@gmail.com \\ Polres Boyolali \\ Widodo Tresno Novianto \\ Email : novianto@consultant.com \\ Supanto \\ Email : supanto8787@gmail.com \\ Dosen Fakultas Hukum Universitas Sebelas Maret
}

\begin{abstract}
This Article aims to find out Policies conducted by Police Boyolali in Controlling Circulation of Alcoholic Beverages in preventing the increase of Criminal Crime acts seta Factors affecting the Distribution of Alcoholic Beverages in Boyolali County Law Police. Is a qualitative deskreptif research, using the concept of the fifth law. Data types use Primary data and Secondary data, data source is Primary Data Source and Secondary Data Source covering Primary Law Material, Secondary Law Material and Tertiary Law Material. Methods of data collection through Interview and the method of Study Library. Data analysis with interactive analysis model. Research shows that Police Police Boyolali policy in Controlling Alcoholic Beverage Distribution in preventing the increase of Criminal Criminal acts in the form of policy of the police is preventive or repressive. The preventive aspect of prevention efforts to prevent crime does not occur with the support and active participation of the community. If prevention efforts fail then the police take repressive measures that are factors that affect both internal and external.
\end{abstract}

Keywords: Alcoholic Beverages; Countermeasures; Policy

\begin{abstract}
Abstrak
Artikel ini bertujuan untuk mengetahui Kebijakan yang dilakukan oleh Polres Boyolali dalam Pengendalian Peredaran Minuman Beralkohol dalam mencegah meningkatnya tindak Pidana Kriminal seta Faktor-Faktor yang mempengaruhi adanya Peredaran Minuman Beralkohol di Wilayah Hukum Polres Boyolali. Merupakan penelitian Deskreptif Kualitatif, menggunakan konsep hukum kelima. Jenis data menggunakan data Primer dan Data sekunder, sumber data adalah Sumber Data Primer dan Sumber Data Sekunder yang meliputi Bahan Hukum Primer, Bahan Hukum Sekunder dan Bahan Hukum Tersier. Metode pengumpulan data melalui Wawancara dan metode Studi Pustaka. Analisis data dengan model analisis interaktif. Penelitian menunjukkan bahwa Kebijakan yang dilakukan oleh Polres Boyolali dalam Pengendalian Peredaran Minuman Beralkohol dalam mencegah meningkatnya tindak Pidana Kriminal berupa kebijakan kepolsian bersifat preventif maupun represif. Aspek preventif yaitu melakukan upaya pencegahan agar tindak kejahatan tidak terjadi dengan adanya dukungan serta partisipasi aktif dari masyarakat. Apabila upaya pencegahan gagal maka polisi mengambil langkah yang bersifat represif yaitu faktor yang mempengaruhi baik internal maupun eksternal.
\end{abstract}

Kata kunci: Minuman Beralkhohol; Penanggulangan; Kebijakan 


\section{A. Pendahuluan}

Dinamika perkembangan teknologi komputer dan internet dalam era globalisasi telah membawa dampak yang signifikan terhadap aktifitas manusia di segala bidang kehidupan, baik dalam skala lokal, skala nasional, maupun global. Perkembangan teknologi yang begitu cepat itu tampaknya sedang melanda dunia saat ini. Hal itu terjadi karena perkembangan teknologi sangat mendukung perkembangan di segala aspek kehidupan yaitu aspek ekonomi, politik, sosial, budaya, maupun dalam bidang teknologi itu sendiri.

Kemajuan teknologi yang sedemikian pesatnya, merupakan produk dari modernitas telah mengalami lompatan yang luar biasa. Karena sedemikian pesatnya, pada gilirannya manusia, sang kreator teknologi itu sendiri kebingungan mengendalikannya. Bahkan bisa dikatakan teknologi berbalik arah mengendalikan manusia. Sebuah revolusi tengah berlangsung dan kita berada di dalamnya. Sebagaimana revolusi-revolusi yang lain, revolusi ini juga membawa perubahan-perubahan yang cepat, cenderung menjungkirbalikkan tatanan-tatanan yang telah lama mapan dan membongkar paradigma-paradigma lama. (Abdul Wahid, 2005: 59).

Dengan adanya perkembangan teknologi yang membawa perubahan pola kehidupan manusia maka mau tidak mau harus mengikuti perubahan itu sendiri agar tidak ketinggalan dalam segala hal. Kondisi ini memberikan sebuah pilihan khususnya bagi Negara-negara berkembang untuk segera mempersiapkan diri dalam menyongsong era globalisasi yang sarat dengan pemanfaatan teknologi tinggi. Posisi Negara berkembang selain dituntut mengejar ketinggalan di bidang ilmu pengetahuan dan teknologi, pembangunan ekonomi, menciptakan masyarakat yang demokratis, diisi lain harus pula memperhatikan pembangunan di bidang hukum yang secara khusus mengatur aktifitas di segala bidang kehidupan dalam skala nasional, regional maupun internasional.

Dalam berkehidupan berbangsa dan bernegara perlu adanya kerjasama yang baik antara pemerintah dan rakyat. Peran dan partisipasi rakyat sangat besar peranannya didalam mewujudkan cita-cita pembangunan. Dengan adanya kerjasama yang baik antara pemerintah dan rakyat dapat diharapkan agar tujuan dan sasaran pembangunan itu akan tercapai sehingga dapat mewujudkan suatu masyarakat yang adil dan makmur. Dalam mewujudkannya pemerintah mengeluarkan berbagai kebijakan dalam penataan tatanan kehidupan masyarakat.

Kebijakan pemerintah yang dilakukan dalam waktu ke waktu tentunya mengalami bertujuan demi perbaikan. Pemerintah tidak akan mengeluarkan kebijakan yang tentunya tidak sesuai harapan. Seperti yang disampaikan oleh Owen Hughes dalam Pan S. Kim. (Pan S. Kim, Vol. 68, hlm 66) : "Summarized for this group: "The administrative paradigma in is terminal stages and unlikely to be revbuved...(It is being replaced by) a new paradigm of public management which pust forward a different relationship betwen government, the public service aand the public". (Paradigma admin istrasi berada pada tahap akhir dan tidak mungkin dibangkitkan kembali... (hal ini digantikan oleh) sebuah paradigma baru tentang manajemen pemerintah yang mengusulkan suatu hubungan yang berbeda antara pemerintah, pelayanan masyarakat dan masyarakat).

Untuk mewujudkan suatu keadaan tersebut, bangsa Indonesia masih menghadapi berbagai masalah yang kurang mendukung, bahkan dapat menjadi hambatan serta 
rintangan untuk pembangunan nasional yang dimana pembangunan nasional tersebut memiliki dampak positif dan negatif.

Dampak positif dari pembangunan nasional itu adalah terwujudnya peningkatan kesejahteraan dan kemakmuran rakyat Indonesia. Sedangkan salah satu dampak negatifnya adalah terjadinya peningkatan kriminalitas dalam berbagai cara dan bentuk. Dampak negatif tersebut sangat besar pengaruhnya dan dapat menghambat kelancaran serta keberhasilan pembangunan.

Salah satu masalah yang sangat memprihatinkan dan harus mendapatkan perhatian serius dari pemerintah ialah masalah minuman keras atau minuman beralkohol yang banyak dikonsumsi oleh masyarakat luas. Mengkonsumsi minuman beralkohol yang berlebihan sangat besar pengaruhnya terhadap sikap dan tindakan pelaku yang mengarah kepada deviasi, seperti kebut-kebutan di jalan raya yang dapat mengganggu lalu lintas, membuat keributan dan kekacauan, dan mengganggu ketenangan masyarakat lainnya. Hal itu disebabkan control diri menjadi berkurang karena mengkonsumsi minuman keras secara berlebihan.

Penyalahgunaan minuman keras (miniman Beralkohol) dengan mengkonsumsinya di luar batas kewajaran, disamping akan menjadi masalah individu yang dapat merugikan diri sendiri, selain itu yang lebih luas lagi dapat menjadi masalah bagi masyarakat. Kebiasaan minum-minuman keras yang melebihi batas yang wajar dapat menyebabkan sikap seseorang menjadi anti sosial dan cenderung merugikan kepentingan orang lain. Disisi lain kebiasaan minum-minuman keras secara berlebihan dapat menyebabkan kecanduan dan menjadi ketergantungan terhadap minuman keras. Mengonsumsi minuman beralkohol tersebut menyebabkan banyak perubahan, ketika mabuk individu tidak mampu mengendalikan diri sehingga melakukan hal-hal yang berlawanan dengan hukum, minuman beralkohol juga dianggap sebagai alat memunculkan keberanian diri (Fatma Rizkia Wardah dan Endang R. Surjaningrum, $2013: 4)$.

Minuman keras adalah minuman yang memabukan dan dapat membahayakan kaum remaja dan harus dijauhi oleh remaja-remaja karena itu akan merusak masa depannya. Sebelum datangnya Islam, masyarakat Arab sudah akrab dengan minuman beralkohol atau disebut juga dengan minuman keras (khamar dalam bahasa arab). (Bambang Irawan, 1998: 42). Dapat kita lihat belakangan ini banyak jatuh korban meninggal dunia yang diakibatkan karena minuman keras oplosan yang selain dikonsumsi secara berlebihan juga dicampur dengan zat-zat kimia yang mematikan yang seharusnya tidak diperuntukkan untuk dikonsumsi manusia. Keadaan yang demikian itu apabila tetap dibiarkan akan menimbulkan keresahan dalam masyarakat juga rusaknya generasi muda yang akan datang. Disamping itu Penggunaan alkohol dalam jumlah yang berlebihan dapat merusak berbagai organ dalam tubuh terutama hati, otakdan jantung. Di samping itu, mengonsumsi minuman beralkohol dapat menyebabkan ketagihan, mabuk dan tidak mampu mengendalikan diri. (Aprianus Arnoldus Tes, Theresia Puspitawati, V Utari Marlinawati,2017 : 4)

Penyalahgunaan alkohol dapat membawa pengaruh yang sedemikian rupa, menyebabkan yang bersangkutan dapat berperilaku yang bertentangan dengan norma 
baik itu norma hukum maupun norma sosial yang hidup didalam masyarakat. Pada intinya Minuman Keras adalah minuman yang memabukan dan dapat membahayakan kaum remaja dan harus dijauhi oleh remaja-remaja karena itu akan merusak masa depannya. Dalam banyak kasus, keduanya (khamer dan alkohol) identik. Remaja merupakan aset negara yang sangat berharga. Seorang remaja bisa merubah dunia dengan pemikirannya. Banyak remaja yang dapat bisa membanggakan negaranya dengan berbagai prestasi yang diraihnya. Remaja memiliki rasa ingin tahu yang sangat tinggi. Rasa ingin tahu sangat berguna bagi seorang remaja karena dengan sifat ini, remaja bisa menjadi manusia yang kreatif dan mau mencari tahu tentang sesuatu yang belum dia ketahuinya. Tapi rasa ingin tahu yang dimiliki remaja bisa menjadi hal yang negatif bila remaja menggunakannya pada hal-hal negatif. Masa remaja adalah masa pencarian jati diri. Pada masa ini remaja mencoba berbagai hal untuk mendapatkan jati diri yang sesungguhnya. Hal yang dilakukan bisa hal yang positif ataupun hal yang negatif. Pada masa ini juga remaja ingin memperlihatkan eksistensinya dimasyarakat, mereka melakukan berbagai hal agar diperhatikan oleh orang di sekelililngnya.

Di era globalisasi ini para remaja, terkadang sulit membedakan mana hal yang boleh dilakukan dan mana hal yang tidak boleh dilakukan. Karena bagi remaja semua hal yang dilakukannya dianggap benar. Kenakalan remaja di era modern ini sudah melebihi batas yang sewajarnya. Banyak anak dibawah umur yang sudah mengenal Rokok, Narkoba, Freesex, dan terlibat banyak tindakan kriminal lainnya. Fakta ini sudah tidak dapat diungkuri lagi, anda dapat melihat brutalnya remaja jaman sekarang. Meningkatnya tingkat kriminal di Indonesia tidak hanya dilakukan oleh orang dewasa, tetapi banyak juga dari kalangan para remaja. Tindakan kenakalan remaja sangat beranekaragam dan bervariasi dan lebih terbatas jika dibandingkan tindakan kriminal orang dewasa.

Saat ini penggunaan minuman keras di luar batas kewajaran (overdosis) banyak sekali terjadi di Indonesia, salah satunya di Polres Boyolali yang dimana masyarakatnya banyak yang menjadi peminat mengkonsumsi minuman keras. Gejala ini dapat dilihat dengan banyaknya tempat-tempat yang menjual minuman keras oplosan. Dengan banyaknya para penjual minuman keras tersebut menyebabkan meluasnya juga konsumen minuman keras dimana untuk mendapatkan minuman keras tersebut menjadi hal yang sangat mudah / gampang sehingga menjangkau kalangan para remaja.

Seringkali kita lihat, terjadinya peningkatan angka kriminalitas yang terjadi didalam masyarakat terutama tindak pidana umum / konvensional seperti pencurian, pemerkosaan, perampokan, penodongan, penganiayaan, serta pengrusakan fasilitas umum, yang dimana tidak sedikit pelakunya berada dibawah pengaruh minuman keras. Hal tersebut itulah yang menguatkan adanya pernyataan serta opini masyarakat bahwa minuman keras dapat memicu tindak kejahatan, oleh karena itu dikaitkan dengan akibat negatif dari penyalahgunaan minuman keras, maka perlu untuk ditindaklanjuti dengan upaya penanggulangan oleh aparat penegak hukum yang dalam hal ini ialah aparat kepolisian. 
Upaya penegakan hukum sebagai salah satu pilar demokrasi paling tidak dipengaruhi oleh empat faktor. Faktor yang pertama ialah hukum itu sendiri, baik dalam arti substansial dari suatu peraturan perundang-undangan maupun hukum formal untuk menegakkan hukum materiil. Kedua ialah profesionalisme penegak hukum. Ketiga, sarana dan prasarana yang cukup memadai. Dan yang keempat ialah persepsi masyarakat untuk hukum itu sendiri.

Polisi sebagai aparatur Negara dalam hal penegakan hukum memiliki kedudukan dan peranan yang sangat penting yaitu sebagai pemelihara keamanan yang dalam implementasinya ialah mencegah dan menanggulangi suatu tindak kejahatan serta pelanggaran. Polisi pada umumnya memiliki dua jenis kekuasaan. Yang pertama ialah kekuasaan polisi dalam bidang hukum, dan yang kedua ialah kekuasaan polisi dalam bidang pemerintahan. Kedua kekuasaan tersebut melahirkan tiga fungsi utama dalam kepolisian yaitu sebagai aparat penegak hukum, sebagai pelayan yang didalamnya termasuk penjaga ketertiban umum, dan sebagai pengayom masyarakat.

Menjalankan tugas dan fungsinya, polisi dapat bersifat preventif maupun represif. Sebagai penjaga ketertiban umum, pada awalnya polisi lebih menekankan pada aspek preventif yaitu melakukan upaya pencegahan agar tindak kejahatan tidak terjadi dengan adanya dukungan serta partisipasi aktif dari masyarakat. Apabila upaya pencegahan gagal maka polisi mengambil langkah yang bersifat represif. Dalam hal penegakan hukum dan pembasmi kejahatan, karakter polisi yang bersifat represif lebih ditonjolkan.

Upaya penanggulangan yang dilakukan aparat kepolisian sejauh ini tidak menunjukkan adanya penekanan terhadap angka kejahatan yang terjadi, malahan tingkat kejahatan semakin hari semakin tinggi. Di sisi lain, perkembangan masyarakat yang menyediakan fasilitas kemudahan publik membuat peredaran minuman keras dalam masyarakat itu sendiri menjadi subur.

Peredaran minuman keras yang tidak terkendali berdampak pada alkoholisme dalam masyarakat dan kejahatan yang terkait dengan minuman keras. Alkoholisme adalah suatu keadaan yang dimana seseorang tidak mampu lagi mengontrol banyaknya jumlah alkohol yang diminumnya. Hal tersebut sekarang yang menjadi tugas dari aparat kepolisian untuk selalu senantiasa aktif dalam mengatasinya. Dengan demikian, peran dari aparat kepolisian sangat dibutuhkan supaya bekerja lebih ekstra lagi dengan cara menindak secara tegas para penjual minuman keras eceran tersebut untuk dapat memberikan efek jera agar keamanan dan ketertiban masyarakat dapat selalu terjaga.

Tidak terkecuali yang ada di wilayah hukum Polres Boyolali. Polres Dalam mencegah atau mengendalikan peredaran minuman Beralkohol (minuman Keras), tentu ada kebijakan-kebijakan atau upaya yang dikeluarkan. Kebijakan yang dikeluarkan tentu bertujuan agar peredaran Minuman Keras atau minuman beralkohol yang ada di wilayah hukum Polres Boyolali lebih terkendali. Berdeasarkan uraian di atas pemasalahan yang dikaji adalah Kebijakan yang dilakukan oleh Polres Boyolali dalam Pengendalian Peredaran Minuman Beralkohol dalam mencegah meningkatnya tindak Pidana Kriminal serta Faktor-Faktor yang mempengaruhi adanya Peredaran Minuman Beralkohol di Wilayah Hukum Polres Boyolali . 


\section{B. Metode Penelitian}

Penelitian ini menggunakan metode pendekatan kualitatif. Penelitian ini mendasarkan pada konsep hukum yang ke-5, yaitu hukum yang ada dalam benak manusia. Lokasi Wilayah Hukum Polres Boyolali. Jenis data yang dipergunakan Jenis data Primer dan Data Sekunder. Sumber data yang dipergunakan Sumber Data Primer dan Sumber data sekunder berupa bahan Hukum Primer, bahan Hukum Sekunder dan bahan Hukum Tersier. Cara pencarian data Dengan Wawancara dan Studi Pustaka. Model analisis kualitatif yang digunakan adalah model analisis interaktif.

\section{Hasil Penelitian dan Pembahasan}

\section{Kebijakan yang dilakukan oleh Polres Boyolali dalam Pengendalian Peredaran Minuman Beralkohol dalam mencegah meningkatnya tindak Pidana Kriminal}

Dalam berkehidupan berbangsa dan bernegara perlu adanya kerjasama yang baik antara pemerintah dan rakyat. Peran dan partisipasi rakyat sangat besar peranannya didalam mewujudkan cita-cita pembangunan. Dengan adanya kerjasama yang baik antara pemerintah dan rakyat dapat diharapkan agar tujuan dan sasaran pembangunan itu akan tercapai sehingga dapat mewujudkan suatu masyarakat yang adil dan makmur. Dalam mewujudkan suatu keadaan tersebut, bangsa Indonesia masih menghadapi berbagai masalah yang kurang mendukung, bahkan dapat menjadi hambatan serta rintangan untuk pembangunan nasional yang dimana pembangunan nasional tersebut memiliki dampak positif dan negatif.

Dampak positif dari pembangunan nasional itu adalah terwujudnya peningkatan kesejahteraan dan kemakmuran rakyat Indonesia. Sedangkan salah satu dampak negatifnya adalah terjadinya peningkatan kriminalitas dalam berbagai cara dan bentuk. Dampak negatif tersebut sangat besar pengaruhnya dan dapat menghambat kelancaran serta keberhasilan pembangunan. Salah satu masalah yang sangat memprihatinkan dan harus mendapatkan perhatian serius dari pemerintah ialah masalah minuman keras yang banyak dikonsumsi oleh masyarakat luas.

Penyalahgunaan minuman keras dengan mengkonsumsinya di luar batas kewajaran, disamping akan menjadi masalah individu yang dapat merugikan diri sendiri, selain itu yang lebih luas lagi dapat menjadi masalah bagi masyarakat. Kebiasaan minum-minuman keras yang melebihi batas yang wajar dapat menyebabkan sikap seseorang menjadi anti sosial dan cenderung merugikan kepentingan orang lain. Disisi lain kebiasaan minum-minuman keras secara berlebihan dapat menyebabkan kecanduan dan menjadi ketergantungan terhadap minuman keras.

Saat ini penggunaan minuman keras di luar batas kewajaran (overdosis) banyak sekali terjadi di Indonesia, gejala ini dapat dilihat dengan banyaknya beredar tempat-tempat yang menjual minuman keras. Dengan banyaknya para penjual minuman keras tersebut menyebabkan meluasnya juga konsumen minuman keras dimana untuk mendapatkan minuman keras tersebut menjadi hal yang sangat mudah / gampang sehingga menjangkau kalangan para remaja. 
Seringkali kita lihat, terjadinya peningkatan angka kriminalitas yang terjadi didalam masyarakat terutama tindak pidana umum / konvensional seperti pencurian, pemerkosaan, perampokan, penodongan, penganiayaan, serta pengrusakan fasilitas umum, yang dimana tidak sedikit pelakunya berada dibawah pengaruh minuman keras. Hal tersebut itulah yang menguatkan adanya pernyataan serta opini masyarakat bahwa minuman keras dapat memicu tindak kejahatan, oleh karena itu dikaitkan dengan akibat negatif dari penyalahgunaan minuman keras, maka perlu untuk ditindaklanjuti dengan upaya penanggulangan oleh aparat penegak hukum yang dalam hal ini ialah aparat kepolisian.

Dalam usaha penanggulangan tindak pidana Minuman Keras tidak terlepas pula dengan adanya visi dan misi Polri untuk mewujudkan masyarakat yang tertib dan aman dari segala bentuk ancaman dan gangguan, visi dan misi itu adalah :

Terwujudnya Postur Polri yang profesional, bermoral dan modern sebagai pelindung, pengayom dan pelayanan masyarakat yang terpercaya dalam melindungi masyarakat dan menegakkan hukum.

Misi Polri adalah sebagai berikut :

1. Memberikan perlindungan, pengayoman dan pelayanan secara mudah, tanggap/ progresif dan tidak diskriminatif agar masyarakat bebas dari segala bentuk gangguan fisik dan psikis.

2. Memelihara keamanan dan ketertiban masyarakat sepanjang waktu di seluruh wlayah serta memfasilitasi keikutsertaan masyarakat dalam memelihara kamtibmas di lingkungan masing-masing.

3. Memelihara kamtibcarlantas untuk menjamin keselamatan dan kelancaran orang dan barang

4. Mengembangkan perpolisian masyarakat (community policing) berbasis pada masyarakat patuh hukum (law Abiding Citizen)

5. Menegakkan hukum secara profesional dan obyektif, proporsional, transparan dan akuntabel untuk menjamin adanya kepastian hukum dan rasa keadilan

6. Mengelola secara profesinal, transparan dan akuntabel seluruh sumber daya Polri guna mendukung keberhasilan tugas Polri

Berdasarkan visi dan misi tersebut, maka kebijaksanaan implementasi juga telah dirumuskan yang mencakup 6 bidang meliputi :

a) Penyempurnaan Grand Strategi Polri 2005-2025, yang tidak menitik beratkan pada pencairan polri semata, tetapi juga memperhatikan aspek-aspek keamanan dalam negeri secara keseluruhan, dengan mempertimbangkan tuntutan kebutuhan masyarakat dan tantangan global termasuk pengamanan wilayah perbatasan dan pulau-pulau terluar

b) Melanjutkan upaya pemeliharaan dan peningkatan sabilitas Kamtibmas melalui program penanggulangan 4 (empat) jenis kejahatan serta akseterasi perpolisian masyarakat

c) Meningkatkan peran dan pemberdayaan penelitian dan pengembangan (Litbang) Polri untuk melakukan kajian dan analisis dampak perkembangan masyarakat terhadap pelaksanaan tugas pokok Polri 
d) Mengintensifkan pemanfaatan teknologi informasi dan komunikasi untuk mewujudkan efisiensi, tranparansi dan akuntabilitas

e) Meningkatkan kerjasama dalam dan luar negeri dalam menghadapi perkembangan dan permasalahan global dengan prinsip kebersamaan dan kemitraan yang saling menguntungkan

f) Menggali kearifan lokal masyarakat dan kearifan internal yang diimbangi dengan kemampuan manajerial pimpinan Polri

Faktor-faktor yang menyebabkan Minuman Keras di masyarakat Boyolali sudah tentu akan timbul tanggapan-tanggapan dari setiap individu dalam masyarakat. pada umumnya masyarakat memandang Minuman Keras itu bertentangan dengan akhlak manusia. Hal ini memang benar, bahwa pada hakekatnya Minuman Keras adalah bertentangan dengan agama, kesusilaan, kepatuhan dan moral, serta dapat membahayakan bagi penghidupan dan kehidupan masyarakat, bangsa dan negara.

Namun melihat kenyataan dewasa ini khusunya di wilayah Boyolali, Minuman Keras dengan segala macam bentuknya masih banyak dilakukan dalam masyarakat. Ditinjau dari segi kepentingan nasional, penyelenggaraan Minuman Keras mempunyai dampak negatif, merugikan moral dan mental masyarakat, terutama terhadap generasi muda. Meskipun kenyataannya juga menunjukkan bahwa hasil Minuman Keras yang diperoleh pemerintah baik pusat maupun daerah dapat digunakan untuk usaha pembangunan, namun dampak negatifnya lebih besar daripada dampak positifnya.

Beberapa program yang dilakukan Polres Boyolali dalam penanggulangan Minuman Keras diantaranya :

\section{POLRES BOYOLALI SETIAP HARINYA}

\begin{tabular}{|c|c|}
\hline RESERSE KRIMINAL & BINAMITRA \\
\hline $\begin{array}{l}\text { 1. Patroli rutin setiap hari } 4 \text { kali, yaitu } \\
\text { pagi, siang, sore dan pada malam hari } \\
\text { 2. Patroli tambahan sewaktu-waktu } \\
\text { jika dianggap perlu (jika ada laporan } \\
\text { masuk dari masyarakat) } \\
\text { 3. Pengintaian terhadap tempat-tempat } \\
\text { yang disinyalir sebagai tempat } \\
\text { Minuman Keras } \\
\text { 4. Penggerebekan setelah adanya data- } \\
\text { data akurat }\end{array}$ & $\begin{array}{l}\text { 1. Penyuluhan rutin kepada masyarakat } \\
\text { minimal sekali dalam sebulan } \\
\text { 2. Pertemuan rutin dengan tokoh } \\
\text { masyarakat dan alim ulama setiap } \\
\text { bulannya untuk mengetahui keadaan } \\
\text { yang berkembang di masyarakat } \\
\text { 3. Memberikan bimbingan kepada } \\
\text { masyarakat yang telah tertangkap } \\
\text { dalam suatu penggerebekan (diberikan } \\
\text { kepada masyarakat yang tertangkap } \\
\text { baik Bandar atau anggotanya) }\end{array}$ \\
\hline
\end{tabular}

Tabel diatas menunjukkan bahwa aparat kepolisian telah melakukan upaya yang maksimal untuk memberantas Minuman Keras, tabel diatas menunjukkan bahwa kepolisian dalam menangani kasus Minuman Keras menggunakan tiga metode yaitu preemtif, preventif dan represif dimana metode preemtif dan preventif di lakukan oleh kesatuan Binamitra dibantu oleh satuan Reskrim dengan menggalakkan patroli. Sedangkan metode represif di lakukan sepenuhnya oleh kesatuan Reskrim. 
Upaya penegakan hukum sebagai salah satu pilar demokrasi paling tidak dipengaruhi oleh empat faktor. Faktor yang pertama ialah hukum itu sendiri, baik dalam arti substansial dari suatu peraturan perundang-undangan maupun hukum formal untuk menegakkan hukum materiil. Kedua ialah profesionalisme penegak hukum. Ketiga, sarana dan prasarana yang cukup memadai. Dan yang keempat ialah persepsi masyarakat untuk hukum itu sendiri.

Polisi sebagai aparatur Negara dalam hal penegakan hukum memiliki kedudukan dan peranan yang sangat penting yaitu sebagai pemelihara keamanan yang dalam implementasinya ialah mencegah dan menanggulangi suatu tindak kejahatan serta pelanggaran. Polisi pada umumnya memiliki dua jenis kekuasaan. Yang pertama ialah kekuasaan polisi dalam bidang hukum, dan yang kedua ialah kekuasaan polisi dalam bidang pemerintahan. Kedua kekuasaan tersebut melahirkan tiga fungsi utama dalam kepolisian yaitu sebagai aparat penegak hukum, sebagai pelayan yang didalamnya termasuk penjaga ketertiban umum, dan sebagai pengayom masyarakat.

Menjalankan tugas dan fungsinya, polisi dapat bersifat preventif maupun represif. Sebagai penjaga ketertiban umum, pada awalnya polisi lebih menekankan pada aspek preventif yaitu melakukan upaya pencegahan agar tindak kejahatan tidak terjadi dengan adanya dukungan serta partisipasi aktif dari masyarakat. Apabila upaya pencegahan gagal maka polisi mengambil langkah yang bersifat represif. Dalam hal penegakan hukum dan pembasmi kejahatan, karakter polisi yang bersifat represif lebih ditonjolkan.

Upaya penanggulangan yang dilakukan aparat kepolisian sejauh ini tidak menunjukkan adanya penekanan terhadap angka kejahatan yang terjadi, malahan tingkat kejahatan semakin hari semakin tinggi. Di sisi lain, perkembangan masyarakat yang menyediakan fasilitas kemudahan publik membuat peredaran minuman keras dalam masyarakat itu sendiri menjadi subur.

Peredaran minuman keras yang tidak terkendali berdampak pada alkoholisme dalam masyarakat dan kejahatan yang terkait dengan minuman keras. Alkoholisme adalah suatu keadaan yang dimana seseorang tidak mampu lagi mengontrol banyaknya jumlah alkohol yang diminumnya. Hal tersebut sekarang yang menjadi tugas dari aparat kepolisian untuk selalu senantiasa aktif dalam mengatasinya. Dengan demikian, peran dari aparat kepolisian sangat dibutuhkan supaya bekerja lebih ekstra lagi dengan cara menindak secara tegas para penjual minuman keras eceran tersebut untuk dapat memberikan efek jera agar keamanan dan ketertiban masyarakat dapat selalu terjaga.

Upaya-upaya yang dapat mendorong penanganan pesta miras antara lain:

\section{a) Melakukan razia terhadap peredaran miras ilegal.}

Salah satu upaya ayang dapat dilakukan Polri untuk menekan angka kejadian pesta miras yang terjadi di masyarakat adalah dengan melakukan razia terhadap miras ilegal. Tugas penertiban ini sesuai dengan yang diamanatkan oleh Undang-Undang Pangan dimana Polri berhak dan wajib untuk menertibkan miras ilegal tanpa izin yang sesuai dengan peraturan perundang-undangan yang berlaku. Upaya penertiban miras ilegal ini akan sangat berpengaruh terhadap penurunan angka kejadian pesta miras karena menurut beberapa kejadian yang terjadi, warga yang melakukan pesta miras biasanya dari golongan ekonomi menengah ke bawah yang mengkonsumsi 
miras lokal ilegal seperti cap tikus, ciyu, bir pletok, dan lain-lain. Polri sangat perlu menertibkan miras ilegal ini karena di dalam miras ilegal ini kadar alkoholnya tergolong tinggi dan tidak sesuai dengan standar yang ditetapkan oleh pemerintah. Dengan kadar alkohol yang tinggi tentunya akan menimbulkan efek yang tidak terkontrol pula bagi peminumnya. Dengan adanya upaya penertiban miras ilegal ini, diharapkan kejadian pesta miras akan menurun karena minuman yang biasa digunakan untuk pesta miras tidak ada lagi di pasaran.

b) Melakukan penertiban terhadap penjual miras yang tidak sesuai dengan aturan.

Selain meminum minuman keras yang ilegal, pesta miras biasanya dilakukan di tempat-tempat umum seperti di pinggir jalan, lapangan atau gardu yang lokasinya berdekatan dengan kios penjual minuman keras tak berizin. Penjual miras tak berizin ini mempunyai kontribusi yang tinggi dalam kejadian pesta miras karena pemerintah selaku pranata sosial tidak dapat mengontrol penjualan barang yang ada di kiosnya, berbeda dengan minimarket atau toko-toko berizin yang secara berkala melaporkan penjualannya kepada pemerintah. Selain itu posisi kios penjual miras tak berizin yang biasanya dekat dengan pemukiman atau tempat berkumpulnya masyarakat ini dapat juga menjadi stimultan bagi orang yang lewat di sekitarnya. Kehadiran kios-kios tidak berizin ini membuat orang yang tidak ada niat meminum alkohol menjadi tertarik untuk meminum alkohol setelah melihatnya. Melihat besarnya dorongan yang ditimbulkan oleh penjual miras tak berizin ini, sudah tepat apabila Polri melakukan pebertiban terhadap penjual miras yang tidak sesuai dengan aturan sehingga dapat menekan angka kejadian pesta miras di masyarakat.

c) Memberi masukan kepada pemerintah untuk membuat peraturan yang lebih ketat.

Polri hanya bisa menegakkan hukum apabila hukum itu sendiri sudah diciptakan oleh pemerintah. Terkadang timbul juga kendala yang dialami Polri saat melakukan penertiban yaitu tidak adanya aturan yang mengatur sehingga Polri tidak dapat melakukan penertiban dengan maksimal. Untuk itu perlu adanya feedback dari Polri kepada pemerintah yang bertugas untuk membuat kebijakan publik dalam bentuk peraturan perundang-undangan sehingga masalah publik dapat ditangani dengan baik. Penyempurnaan kebijakan publik ini merupakan sebuah proses yang wajar dan selazimnya ada untuk memperoleh sebuah formula kebijakan publik yang ideal bagi masyarakat. Dalam hal ini adalah kebijakan publik yang mengatur mengenai minuman keras sehingga masalah publik seperti pesta miras ini dapat diatasi.

d) Menggalakkan sambang kepada masyarakat untuk menyampaikan himbauan agar menghindari pesta miras.

Selain upaya represif seperti penertiban atau penegakkan hukum, upaya preventif juga perlu dilakukan oleh Polri. Upaya ini dapat dilakukan dengan melakukan sambang kepada masyarakat untuk menyampaikan himbauan agar menghindari pesta miras. Anggota Polri yang jumlahnya banyak ini dapat berkunjung kepada masyarakat untuk memberikan informasi tentang bahaya minuman keras dan akibatnya bagi lingkungan sehingga masyarakat dapat berfikir untuk menghindari minuman keras. Upaya ini selain dapat mendorong warga untuk tidak meminum 
minuman keras juga dapat mencegah generasi muda yang belum pernah mencoba minuman keras untuk tidak melakukannya. Hal ini kemudian dapat membentuk budaya anti miras di lingkungan masyarakat. Ketika budaya anti miras sudah terbentuk maka upaya kontrol sosial dapat dilakukan tidak hanya oleh Polri tapi juga oleh masyarakat. Keadaan ini nantinya akan mempermudah penanggulangan pesta miras yang ada di masyarakat.

\section{Faktor-Faktor yang mempengaruhi adanya Peredaran Minuman Beralkohol di Wilayah Hukum Polres Boyolali}

Penyalahgunaan alkohol lebih umum terjadi di masyarakat yang berpendapatan rendah dan kurangnya pendidikan.

\section{a. Akibat rendahnya tingkat pendidikan dan ekonomi mayarakat}

Akibat rendahnya tingkat pendidikan dan ekonomi mayarakat maka banyak dari para remaja dan orang dewasa menganggur, mau bekerja sebagai PNS tidak mungkin kerena hanya tamat SMA, mau membuka usaha tapi modal tidak ada, pilihan mereka hanya bekerja sebagai petani, namun banyak remaja yang merasa gengsi dan malu menekuni pekerjaan tersebut, terutama terhadap teman-teman mereka yang dari luar daerah Sidemen. Tidak ada kegiatan, mereka lebih memilih untuk berkumpul dengan sesamanya, berjudi, sambil ditemani minum minuman keras tentunya. Di seluruh belahan dunia perilaku berjudi dan minum minuman keras merupakan sebab utama terjadinya kemiskinan di suatu daerah, sehingga daerah tersebut menjadi menjadi sulit untuk berkembang dan bersaing dengan daerah lain.

\section{b. Kebudayaan dan Latar Belakang Kehidupan}

Salah satu faktor yang mendorong berkembangnya perilaku minum minuman beralkohol adalah kebudayaan serta latar belakang kehidupan seseorang. Karena kebiasaan yang sudah membudaya ini maka muncul kecenderungan untuk merasionalkan norma-norma dan nilai-nilai menurut persepsi dan kepentingan mereka sendiri. Penyimpangan perilaku berupa minum minuman keras ini dilakukan dengan cara mengikuti arus pelaku lainnya melalui sebuah proses pembenaran

Jadi secara tidak langsung kebudayaan masyarakat ikut membantu perkembangan perilaku menyimpang di masyarakat berupa minum minuman keras. Latar belakang kehidupan seseorang juga berpengaruh menentukan perilaku seseorang di masyarakat termasuk berbagai bentuk penyimpangan seperti minum minuman keras. Orang yang pada masa kecilnya bergaul bersama dengan pemabuk tentu akan cinderung untuk menjadi pemabuk juga. Hal tersebut karena dalam lingkungan sosial, seseorang cinderung untuk berusaha diterima olah kelompok sosialnya dengan cara mengikuti perilaku dan gaya hidup mereka.

\section{Tidak Adanya Peran Orang Tua dan Tokoh Masyarakat Sebagai kontrol Sosial}

Masa kanak-kanak dan remaja adalah masa dimana seseorang belajar untuk meniru berbagai perilaku orang yang berada di lingkungannya untuk kemudian dipahami dan 
sebagai suatu bentuk nilai yang sering disebut sebagai proses imitasi. Dalam proses imitasi orang tua adalah berperan sangat penting dalam membentuk kepribadian seseorang, anak-anak akan cenderung untuk meniru perbuatan orang tua yang dianggap sebagai orang terdekat.

Masalah yang terjadi adalah banyaknya orang tua yang bukannya memberikan contoh baik, mereka malah minum minuman keras di depan anak-anak tanpa memikirkan dampak yang akan timbul. Anak-anak yang menyaksikan orang tua mereka minum mendapatkan nilai bahwa seakan-akan minum minuman keras itu adalah sesuatu yang wajar sehingga mereka cenderung berprilaku yang sama dengan orang tua mereka. Selain karena contoh buruk yang diberikan, masalah lain adalah tidak adanya peran orang tua sebagai kontrol sosial sehingga norma serta nilai luhur yang seharusnya dijaga terkesan terabaikan.

Akibat dari tidak adanya kontrol sosial tersebut menyebabkan timbulnya berbagai bentuk penyimpangan sosial. Penyimpangan sosial dapat diartikan sebagai perilaku yang tidak berhasil menyesuaikan dengan norma-norma di masyarakat, artinya penyimpangan tersebut terjadi jika seseorang tidak mematuhi patokan norma yang sudah ada. Disfungsi dari perilaku menyimpang dapat menyebabkan terancamnya kehidupan sosial, karena tatanan sistem yang sudah ada dapat tidak berjalan sebagaimana mestinya karena ada individu yang tidak dapat menjalankan tugasnya dalam sistem masyarakat.

Minum minuman keras sudah selayaknya diberantas karena dampak negatif yang dapat ditimbulkan selain kerena dalam ajaran agama tertentu minum minuman keras adalah perbuatan yang dilarang. Cara yang paling tepat dalam memberantas suatu masalah adalah dengan cara mencari sumber permasalahan tersebut. Sehingga apabila sumber permasalahan tersebut terselesaikan maka masalah-masalah lain tidak akan timbul atau muncul kembalii. Begitu pula dengan pemberantasan minum minuman keras di Sidemen. Motif seseorang menjadi alcoholic tentu berbeda-beda, sehingga untuk mencari tahu sumber permasalahnnya diperlukan suatu konseling. Namun perkembangan konseling sebenarnya sangat lambat sampai peminum itu sendiri benar-benar menganbil keputusan untuk berhenti minum.

Salah satu faktor yang menghambat adalah kerena alkohol bersifat aditif sehingga peminum yang berusaha untuk berhenti akan mengalami sindrom putus obat yaitu keadaan yang sangat tidak menyanangkan dari tubuh akubat kekurangan zat aditif. Biasanya cairan infus, magnesium dan glukosa sering diberikan untuk mencegah beberapa gejala putus obat dan untuk menghindari dehidrasi atau bisa juga dengan pembarian benzodiazepin selama beberapa hari untuk menenangkan dan membantu mencegah gejala putus obat. Obat-obatan anti-psikosa umumnya diberikan untuk sejumlah kecil pecandu dengan halusinasi alkoholik. Setelah masalah medis darurat berhasil diatasi, program detoksikasi dan rehabilitasi harus dimulai. Pada tahap pertama pengobatan, alkohol sama sekali tidak digunakan. Kemudian seorang pecandu harus mengubah perilakunya. Tanpa bantuan, sebagian besar pecandu akan kambuh dalam beberapa hari atau beberapa minggu. Seorang alcoholic dapat dikatakan sembuh dari pengaruh minuman keras tidak hanya dilihat dari berhentinya ia minum minuman keras, namun juga dari kesembuhan tubuhnya yang telah rusak akibat minum minuman keras, caranya mengatasi tekanan hidup, serta cara mengatasi rasa percaya diri dan rasa bersalah. 


\section{Simpulam}

Berdasarkan pembahasan yang telah disajikan, maka dapat disimpulkan bahwa :

1. Kebijakan yang dilakukan oleh Polres Boyolali dalam Pengendalian Peredaran Minuman Beralkohol dalam mencegah meningkatnya tindak Pidana Kriminal

Menjalankan tugas dan fungsinya, polisi dapat bersifat preventif maupun represif. Sebagai penjaga ketertiban umum, pada awalnya polisi lebih menekankan pada aspek preventif yaitu melakukan upaya pencegahan agar tindak kejahatan tidak terjadi dengan adanya dukungan serta partisipasi aktif dari masyarakat. Apabila upaya pencegahan gagal maka polisi mengambil langkah yang bersifat represif. Dalam hal penegakan hukum dan pembasmi kejahatan, karakter polisi yang bersifat represif lebih ditonjolkan.

2. Faktor-Faktor yang mempengaruhi adanya Peredaran Minuman Beralkohol di Wilayah Hukum Polres Boyolali

Faktor yang menpengaruhi seseorang menjadi alcoholic ada dari faktor internal maupun eksternal. Faktor internal misalnya, gen, keadaan psikologis dan kerohanian. Sedangkan faktor eksternal antara lain tingkat pendidikan, ekonomi, latar belakang kehidupan, budaya, serta kerana tidak adanya kontrol sosial di masyarakat.

\section{E. Saran}

Saran yang dapat disampaikan antara lain adalah :

1. Untuk menangani permasalah pesta miras di masyarakat, Polri sebagai salah satu lembaga pemerintah perlu melakukan upaya-upaya terkait tugas dan wewenangnya sehingga permasalahan pesta miras ini dapat diatasi. Upaya-upaya itu antara lain dengan melakukan razia terhadap peredaran miras ilegal, melakukan penertiban terhadap penjual miras yang tidak sesuai dengan aturan, memberi masukan kepada pemerintah untuk membuat peraturan yang lebih ketat, menggalakkan sambang kepada masyarakat untuk menyampaikan himbauan agar menghindari pesta miras.

2. Kepada masyarakat diharapkan memahami dan menyadari akan arti penting bahaya mengkonsumsi minuman keras, karena dampaknya tidak baik bagi kesehatan dan juga dapat menimbulkan keresahan dalam masyarakat.

\section{F. Daftar Pustaka}

Abdul Wahid, 2005, Teknologi Komputer dan Pengaruhnya, Jakarta, Gramedia.

Andi Hamzah, 1990. Aspek-aspek Segi Pidana di Bidang Komputer, Jakarta. Sinar Grafika

Bambang Sunggono.1994. Hukum dan Kebijaksanaan Publik. Jakarta: Sinar Grafika

Bambang Irawan, 1999, Minuman Keras dan Bahayanya Bagi Generasi Muda, Jakarta, Sinar Grafika

Bambang Waluyo.1991. Pemeriksaan dan Peradilan di Bidang Perpajakan. Jakarta: Sinar Grafika

Budi Winarno. 2002. Teori dan Proses Kebijakan Publik. Yogyakarta : Media Pressindo. 
C.S.T. Kansil, 2001.Pemerintah Daerah di Indonesia. Jakarta : Sinar Grafika

Esmi Warassih Pujirahayu,2005. Pranata Hukum sebuah Telaah Sosiologis, Semarang: Suryandaru Utama

B. Sutopo. 1988. Metodologi Penelitian Kualitatif. Surakarta: UNS Press.

Imam Losari, 2009, Bahaya Minuman Keras, Bandung, Alumni

Institut Komputer Indonesia, 1981. Mengenal Komputer dan masalahnya, Jakarta, Gramedia.

Randy Reddick dan Elliot King. 1996. Internet Untuk Wartawan Internet Untuk Semua Orang, Yogyakarta : Liberty.

Satjipto Rahardjo. 1997. Sosiologi Hukum : Perkembangan, Metode dan Pilihan Masalah, Cetakan 1. Muhammadiyah University Press, Surakarta

Setiono, 2005, Pemahaman terhadap Metode Penelitian Hukum, (Diktad). Surakarta: Program Studi Ilmu Hukum Pascasarjana UNS.

Soerjono Soekarnto, 1986, Pengantar Penelitian Hukum. Jakarta : U1-Press.

Soetandyo Wognjosoebroto, 2002. Hukum. Paradigma dan Dinamika Masalahnya. Jakarta: Lembaga Studi dan Advokasi Masyarakat (ELSAM) dan Perklumpulan untuk Pembaharuan Hukum Berbasis Masyarakat dan Ekologi (HuMa).

Thomas R. DYE, 1981, Understanding Public Policy. Florida: State University

\section{Undang-Undang :}

Undang-Undang No. 2 Tahun 2002 tentang Kepolisian Negara Republik Indonesia

Undang-Undang Mo. 23 tahun 2014 tentang Pemerintahan Daerah

\section{Jurnal :}

Aprianus Arnoldus Tes, Theresia Puspitawati, V Utari Marlinawati, 2017, Fenomena Perilaku Mengkonsumsi Minuman Keras Mahasiswa Program Studi S-1 Kesehatan masyarakat Universitas Respati Yogyakarta, Jurnal Formil (Forum Ilmiah) KesMas Respati, Volume 2, Nomor 1, April 2017

Fatma Rizkia Wardah dan Endang R. Surjaningrum, 2013, Pengaruh Ekspektansi pada Minuman Beralkohol terhadap Konsumsi Minuman Beralkohol, Jurnal Psikologi Klinis dan Kesehatan Mental, Fakultas Psikologi Universitas Airlangga vol.02 No. 02, Agustus 2013

Pan S. Kim, Civil Service reform in Japan and Korea toward Competitiveness and competency, International Review of Administrative Science. Vol. 